udało się pozyskać wybitnych znawców problematyki historii wychowania, którzy poprzez swoje teksty ukazali istniejące bogactwo i różnorodność źródeł, możliwych i koniecznych w badaniach naukowych.

Biorąc do ręki powyższą pracę jesteśmy mile wprowadzeni w klimat świata archiwaliów i innych źródeł dzięki sugestywnej ilustracji na okładce, przedstawiajacej dzieło J. D. de Heema „Martwa natura z książkami”. Powyższy klimat wzmacniają umieszczone na wewnętrznych stronach okładki aforyzmy sześciu wybranych historyków, pochodzące z pracy A. Łaskiego „O historii: sentencje - myśli - aforyzmy".

Andrzej Kusztelak

\title{
Danuta Koźmian, Janusz Jędrzejewicz polityk i pedagog (1885-1951), Wydawnictwo Naukowe Uniwersytetu Szczeciń- skiego, Szczecin 2004, s. 171
}

We współczesnej polskiej humanistyce zauważalny jest wyraźnie kierunek badań biograficznych. Dotyczy to nie tylko oczywistej w tym miejscu historii, ale także psychologii, socjologii, filologii, i oczywiście pedagogiki ${ }^{1}$. Przykladem populamości tej formy narracyjnej wśród historyków wychowania jest jedna $\mathrm{z}$ najnowszych publikacji Wydawnictwa Naukowego Uniwersytetu Szczecińskiego, praca Danuty Koźmian, „Janusz Jędrzejewicz polityk i pedagog (1885-1951)".

Autorka postawiła przed sobą bardzo ambitne zadanie. Postanowiła bowiem ukazać postać J. Jędrzejewicza jako polityka i pedagoga, przedstawić polską myśl pedagogiczną okresu międzywojennego (w tym powstanie i założenia ideowe grupy sanacyjnej Zrąb, do której Jędrzejewicz należal, a także recepcję ustawy o ustroju szkolnictwa z 11 marca 1932 roku i jej przyjęcie przez organizacje nauczycielskie i partie polityczne), a także zrekonstruować dzieje wychowania państwowego w Polsce od XVI do końca XIX wieku. Ta wielokierunkowość badań została poniekad podyktowana potrzeba weryfikacji dotychczasowego stanu wiedzy, bo jak zauważyła autorka w „Uwagach wstępnych", ,wiele dotychczasowych prac wymaga głębszego spojrzenia lub nawet rewizji ze strony obecnych badaczy, gdyż pozwoliłoby to na swoiste «przywrócenie godności» potępianym poprzednio pedagogom i politykom oraz na ponowne zweryfikowanie oceny ich poglądów i działalności"2. Do takich postaci J. Jędrzejewicz właśnie przez długie lata należał. I to pomimo faktu, iż należał do najwybitniej- szych i najciekawszych postaci okresu Drugiej Rzeczypospolitej. Dla przypomnienia dodać może warto, że był on legionista Piłsudskiego, nauczycielem, politykiem i ministrem wyznań religijnych i oświecenia publicznego, publicysta, i w końcu także autorem reformy szkolnictwa polskiego w latach trzydziestych. Zjadliwość historii polega na tym, że sam Jędrzejewicz długo pozostawal w cieniu owej reformy, która przestoniła postać swego twórcy. Bo jak dotąd jego źycie i działalność na innych polach nie kusiła historyków wychowania, mimo iż badawczo były bardzo atrakcyjne, bo obejmowały one kilka epok historycznych (okres niewoli narodowej, I wojna świato wa, II RP, II wojna światowa, okres powojenny).

D. Koźmian, autorka kilku innych prac o charakterze biograficznym (np. poświęconych H. Rowidowi, F. W. Foersterowi i in.), przyjęła, iż prezentowana praca winna mieć charakter historyczno-pedagogiczny o ukfadzie chronologiczno-problemowym. W badaniach swych oparła się na źródłach archiwalnych i drukowanych, znajdujacych się w Bibliotece Narodowej, Bibliotece Głównej Uniwersytetu im. A. Mickiewicza w Poznaniu, Wojewódzkiej Bibliotece Pedagogicznej im. H. Radlińskiej w Szczecinie, Książnicy Szczecińskjej i Bibliotece Glównej Uniwersytetu Szczecińskiego. Autorka przeprowadzila także kwerendę prasowa, wykorzystała bowiem część prasy pedagogicznej okresu międzywojennego: „Głos Nauczycielski”, „Kwartalnik Pedagogiczny”, „Muzeum”, „Oświatę i Wychowanie”. Specjalne miejsce znalazło czasopismo o charakterze społecznym „Zrab”. Przodujacymi jednak źród-

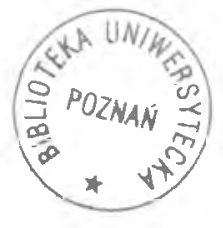


łami były dla D. Koźmian pamiętniki i fragmenty innych prac J. Jędrzejewicza zebrane w pracy „W służbie idei”, wydanej w Londynie w 1972 roku. Baza źródłowa wzbogacona została ponadto Sprawozdaniami stenograficznymi Sejmu i Dziennikami Ustaw Rzeczypospolitej Polskiej z okresu międzywojennego.

Praca składa się z pięciu rozdziałów. Pierwszy dotyczy genezy i założeń wychowania państwowego na tle warunków politycznych i oświatowych Drugiej Rzeczypospolitej. Rozdzial drugi przedstawia życie i działalność polityczna, spoleczną oraz pedagogiczną J. Jędrzejewicza. Kolejna częsć pracy opisuje powstanie i aktywność grupy sanacyjnej Zrab, charakteryzuje jej czasopismo i ukazuje jego miejsce na tle reszty prasy oświatowej okresu międzywojennego. Czwarty rozdział został natomiast poświęcony działalności pisarskiej i pogladom społeczno pedagogicznym $\mathbf{J}$. Jędrzejewicza, gdzie glównym wątkiem jest idea wychowania państwowego. Ostatnia część pracy dotyczy wszystkiego, co miało związek z ,ustawa Jędrzejewicza”: okoliczności jej uchwalenia, jej treść, cel i znaczenie aktu, a także oceny w opinii tak srodowiska nauczycielskiego, jak i elit politycznych Drugiej Rzeczypospolitej.

Tak więc autor najslynniejszej ustawy szkolnej $\mathrm{w}$ historii Polski XX wieku doczekal się swojej biografii. I pomimo, iż promieniuje $z$ niej wyraźna fascynacja bohaterem autorki, która sama w „Uwagach wstępnych" osobiście przestrzegała przed oczywistym brakiem obiektywizmu w badaniach biograficznych, to dobrze się stało, że ukazała się ona właśnie teraz, bo jak zauważyła D. Koźmian w ostatnich strofach swojej ksiażki, ,dorobek (...) ustawy z 1932 roku wyraźnie - chociaż w innych warunkach społecznych i odmiennych wyzwaniach cywilizacyjnych kontynuowany jest we współczesnym ustroju szkolnym".

\section{Edyta Glowacka-Sobiech}

${ }^{\prime} \mathrm{Cz}$. Majorek, Rola badań biograficznych w rekonstrukcji dziejów oświaty i pedagogiki w Galicji [w:] Galicja $i$ jej dziedzictwo, t. 9: Biografie pedagogiczne, pod red. Cz. Majorka i J. Potocznego, Rzeszów 1997, s. 11 -24; tenże, Biografia edukacyjna [w:] Śladami przeszlości i czasów wspótczesnych. Ksiega ofiarowana Profesorowi Lechowi Mokrzeckiemu z okazji Jego jubileuszu, Gdańsk 1996, s. 178 - 187; E. Podgórs$\mathrm{ka}$, Problemy metodologiczne prac biograficznych w zakresie historii wychowania, ,Rozprawy z Dziejow Oświaty" 1989, t. 32, s. 183-195; G. Zalejko, Biografistyka historyczna zarys ewolucji kierunku, „Historyka”, t. XVIII, 1988, s. 37-55; E. Glowacka-Sobiech, Rola $i$ zadania badan biograficznych $w$ humanistyce $z$ uwzględnieniem szczególnym biografii edukacyjnej $i$ jej miejsca w historii wychowania, w druku.

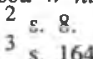

\section{Opowiadanie historii w niemieckiej refleksji teoretycz- no-historycznej i literaturoznawczej od oświecenia do współcze- sności, wybór, przekład i opracowanie Jerzy Kałążny, Wydaw- nictwo Poznańskie, Poznań 2003, s. 660}

Od lat dziewięćdziesiątych ubiegłego już stulecia Wydawnictwo Poznańskie obdarowuje swoich czytelników książkami wydawanymi we wspólnym cyklu „Poznańska Biblioteka Niemiecka". Tym samym wydawnictwo to podtrzymuje chlubną poznańską tradycję badań niemcoznawczych, znaczonymi chociażby praca i działalnościa Instytutu Zachodniego, czy też aktywnościa na tym polu uczonych, zwiazanych $z$ Uniwersytetem im. A. Mickiewicza, podług bardzo trafnie wybranego motta tomu, że ,sasiedztwo zobowiązuje, [a] zwłaszcza wtedy, gdy pamięć sassie- dztwa różni mocno, a niepięknie. Taka pamięć dzieli i łączy. Jako wspólne doświadczenie warunkuje współczesność"!.

Jedna $\mathrm{z}$ ostatnich inicjatyw Wydawnictwa Poznańskiego jest publikacja Opowiadanie historii $w$ niemieckiej refleksji teoretyczno-historycznej i literaturoznawczej od oświecenia do wspótczesności. Praca to powstała głównie dzięki Jerzemu Kałążnemu, który podjał się nie tylko wyboru źródeł, ale także przekładu i opracowania. Zważywszy natomiast na „bagaż intelektualny" i naturalną trudność w percepcji tekstów metodo- 